\title{
ACTUAL PROBLEMS OF COVERT INVESTIGATION
}

\section{Podobnyi O. O.}

\section{INTRODUCTION}

Covert investigative (detective) actions" (hereinafter - CI(D)A) in accordance with Art. 246 CCP is a type of CI(D)A, information about the fact and methods ${ }^{1}$ of conducting which are not subject to disclosure. Based on the stated legislative requirement, which prohibits detailed disclosure in the open source of the features of tactics, and especially technology, CI(D)A, the subject of this unit will become the general principles of the organization and tactics of their conduct.

CI(D)A shall be conducted in cases where the information about the crime and the person who committed it cannot be obtained otherwise, ie by conducting the I (D) A, as well as exclusively in criminal proceedings for serious or particularly serious crimes (except use of confidential cooperation and location of electronic means).

\section{General provisions for conducting Covert investigative (detective) actions}

The peculiarities of the actions provided for in Chapter 21 of the CCP and the introduction of the term "unspoken" on the one hand emphasize the differences from the "traditional" investigator's toolbox, such as CI(D)A, and, on the other, make it necessary to observe their implementation of such principle, which is elaborated by the theory of operative-search activity, as a conspiracy.

The principle of conspiracy to carry out the CI(D)A requires that the following three requirements be met: 1) the persons to whom they are committed should not be aware of these actions; 2) a similar approach to employees of investigative and operational units who are not organizers or executors of the $\mathrm{CI}(\mathrm{D}) \mathrm{A}$; 3) strict and steady securing of the regime of secrecy, as a special procedure for circulation of those documents and other material media of information, which are the property of the state and are protected by the Laws of Ukraine "On State Secret" and the CPC.

1 Про затвердження Інструкції про організацію проведення негласних слідчих (розшукових) дій та використання їх результатів у кримінальному провадженні: Наказ Генеральної прокуратури України, Міністерства внутрішніх справ України, Служби безпеки України, Державної прикордонної служби України, Міністерства фінансів України, Міністерства юстиції України від 16.11.2012 № 114/1042/516/1199/936/1687/5. 
Possibilities of a conspiratorial holding of the CI(D)A complex in the fOCGework of criminal proceedings, provided by the legislator in Art. 246, 253 of the CCP, which provide for a maximum term of such action in eighteen months and the moment of notification of the fact and the results of its conduct within twelve months from the date of termination of the action, but not later to appeal to the court with the indictment, - allow to establish the actual existence of criminal- the law institute of unspoken investigation as a special form of pre-trial investigation. Further development of the methodology for conducting such an investigation is an urgent task of forensic science.

The subjects of the CI(D)A are the investigator who carries out the pretrial investigation of the crime or, on his or her behalf, the authorized operational units.

Classification of $\mathrm{CI}(\mathrm{D}) \mathrm{A}$ is possible by many criteria: 1) procedural (actions related to interference with private communication and others; actions carried out exclusively in criminal proceedings for serious and particularly serious crimes and those carried out regOSAless of the gravity of the crime); 2) by an official who gives permission for their conduct (with the permission of the head of the pre-trial investigation body, the prosecutor, the investigating judge); 3 ) by the method, as a way of organizing the practical development of reality, which is the basis of the action (personal, technical); 4) by the authorized unit (person) - the direct executor of the working stage of the CI(D)A.

According to the last of these criteria, which in terms of forensics is the most relevant in covering the organizational and tactical aspects of the CI(D)A, it is advisable to highlight the actions that are carried out:

1) operational and technical units: 1.1) audio and video control of a person (Article 260 of the CPC); 1.2) removal of information from transport telecommunications networks (Article 263 of the CPC): 1.2.1) control over telephone conversations; 1.2.2) removal of information from communication channels; 1.3) removal of information from electronic information systems without the knowledge of its owner, owner or holder (Article 264 of the CPC); 1.4) establishment of the location of the electronic means (Article 268 of the CPC); 1.5) examination of publicly inaccessible places, housing or other possession (Article 267 of the CPC); 1.6) audio and video control of the place (Article 270 of the CPC);

2) operational units specializing in qualified visual observation observation of a person, thing or place (Article 269 of the CCP): 2.1) surveillance of a person in publicly accessible places; 2.2) observing the year or place in publicly accessible places; 
3) investigative or authorized operational units that are competent to organize the conduct of all CI(D)A: 3.1) removal of information from electronic information systems, access to which is not restricted by its owner, owner or holder or is not related to overcoming the logical protection system (Article 264 of the CCP); 3.2) unspoken receipt of samples required for comparative study (Article 274 of the CPC); 3.3) controlled and operational procurement; 3.4) controlled delivery; 3.5) a special investigative experiment; 3.6) simulating the situation of the crime; 3.7) arresting correspondence (Article 261 of the CPC); 3.8) review and withdrawal of correspondence (Article 262 of the CPC); 3.9) monitoring of bank accounts;

4) covert employees: 4.1) performing a specific task of disclosing criminal activity of an organized group or criminal organization (Article 272 of the CPC); 4.2) the use of confidential cooperation (Article 275 of the CPC).

At the organizational and tactical level, any CI(D)Ais carried out in three stages: 1) preparatory (organization and planning); 2) working (direct); 3 ) final (recording and documenting the results).

The criminal procedural legislation in a general form defines the content of both the preparatory and the final stages of the CI(D)A. At the same time, the tactics, and especially the technology, of the working stage of the CI(D)Ais directly the prerogative of methodological recommendations developed by forensic science and theory of operative-investigative activity on the basis of practice materials, formalized at the level of instructions with the restriction of access of bodies, within which there are authorized operational units.

At the preparatory stage, first of all, a decision is made to hold the $\mathrm{CI}(\mathrm{D}) \mathrm{A}$. This is the responsibility of the investigator, the prosecutor, and in the cases provided for by the CPC, the investigating judge at the request of the prosecutor or at the request of the investigator, agreed with the prosecutor.

The resolution of the investigator, the prosecutor on the conduct of the CI(D)A must contain: 1) the name of the criminal proceedings and his registration number; 2) the legal qualification of the crime, indicating the article (part of the article) of the CCP; 3 ) information about the person (s), place or thing in respect of which the $\mathrm{CI}(\mathrm{D}) \mathrm{A}$ will be conducted; 4) the beginning, duration and purpose of the CI(D)A; 5) information about the person (s) who will conduct the CI(D)A; 6) substantiation of the adopted resolution; 7) an indication of the type of emergency I(D) A being conducted. 
If an investigating judge makes a decision on the conduct of a particular $\mathrm{CI}(\mathrm{D}) \mathrm{A}$, as required by the $\mathrm{CCP}$, he or she is required to consider the request within six hours of receiving it. The petition is considered with the participation of the person submitting the petition.

The petition shall state: 1 ) the name of the criminal proceedings and its registration number; 2) a summary of the circumstances of the crime in connection with which the request is being investigated; 3) legal qualification of the crime, with an indication of the article (part of the article) of the Criminal Code of Ukraine (hereinafter - the Criminal Code); 4) information about the person (s), place or thing, for which it is necessary to carry out $\mathrm{CI}(\mathrm{D}) \mathrm{A} ; 5)$ circumstances giving grounds to suspect a person of committing a crime; 6) type of $\mathrm{CI}(\mathrm{D}) \mathrm{A}$ and justification of the term of its holding; 7) justification of the inability to obtain information about the crime and the person who committed it in another way; 8) information, depending on the type of $\mathrm{CI}(\mathrm{D}) \mathrm{A}$, about identification features that will allow uniquely identifying the subscriber of the surveillance, telecommunication network, terminal equipment, etc.; 9) substantiation of the possibility of obtaining, during the $\mathrm{CI}(\mathrm{D}) \mathrm{A}$, evidence which alone or in combination with other evidence may be of significant importance for clarifying the circumstances of the crime or identifying the perpetrators.

An excerpt from the Unified Register of Pre-trial Investigations on Criminal Proceedings under which the motion is filed shall be attached to the request of the investigator, the prosecutor.

The decision of the investigating judge on the permission to hold the CI(D)A must contain information about: 1) the prosecutor, the investigator who applied for the petition; 2) a crime in connection with which a pre-trial decision is ruled; 3 ) the person (s), place or thing in respect of which it is necessary to carry out the CI(D)A; 4) type of CI(D)A and information on identification features that will allow uniquely identifying the subscriber of the surveillance, telecommunication network, terminal equipment, etc.; 5) the validity period of the decision.

The latter may not exceed two months. Where necessary, the term of the CI(D)A may be extended in accordance with the requirements of the legislation.

In exceptional cases of urgency relating to the saving of human life and the prevention of the commission of a serious or particularly grave crime provided for in Sections I, II, VI, VII (Articles 201 and 209), IX, XIII, XIV, XV, XVII of the Special Part of the Criminal Code, The CI(D)A may be initiated pending the decision of the investigating judge in the cases provided for by the $\mathrm{CCP}$, at the discretion of the investigator agreed with the prosecutor or the prosecutor. In such a case, the prosecutor is obliged to 
immediately apply to the investigating judge immediately after the start of such CI(D)A.

The investigator, the prosecutor, sends the instruction to the head of the body, which includes operational units, authorized to conduct the CI(D)A. In the case where the materials of the investigative activity were used as a pretext and basis for the initiation of a pre-trial investigation, a warrant for the execution of the $\mathrm{CI}(\mathrm{D}) \mathrm{A}$ is usually given to the operative unit that detected the crime, but its powers are taken into account. Prior to the order of the investigator, the prosecutor shall be accompanied by the decision of the investigating judge on the permission to hold the $\mathrm{CI}(\mathrm{D}) \mathrm{A}$ or the decision of the investigating prosecutor to hold the CI(D)A. The authorized operational unit for the execution of the order of the investigator, the prosecutor, taking into account the need to ensure the conditions for the execution of the CI(D)A, shall, on the basis of its task, involve the relevant operational and operational-technical units.

The criminal procedural legislation provides that at the final stage there is a fixing and documenting of the results of the CI(D)A. In accordance with the requirements of the CCP on the results of the $\mathrm{CI}(\mathrm{D}) \mathrm{A}$, a protocol is drawn up, which, if necessary, shall be accompanied by annexes (specially made copies, samples of objects, things and documents, written explanations of the specialists who participated in the respective action, a transcript, audio, video, photo tables, schematics, casts, computer media, and other materials explaining the content of the protocol).

Information on persons who conducted or were involved in the CI(D)A may, in the case of security measures, be provided with the confidentiality of such persons in accordance with the procedure established by law. The conduct of CI(D)A can be fixed by technical and other means.

CI(D)A the use of technical means, items removed during the process and documents or copies thereof may be used in proving on the same grounds as the results other I(D)A during the pre-trial investigation.

The frequency of drawing up protocols depends on the type of CI(D)A, its duration (at one time or over time), on the instructions of the investigator, the prosecutor, but in any case immediately after obtaining factual data that can be used as evidence to establish the whereabouts of the person. wanted case by case, review, recess, investigation of the results of the fraudulent investigative action, etc.

According to the results of the order of the investigator, the operative employee makes a report indicating the results of the executed order, the forces and means involved, as well as their results. The head of the authorized operational unit makes the decision by imposing a resolution on the report regOSAing the possibility of sending the protocol and its 
attachments to the prosecutor or taking measures for the proper execution of the order. The report and its annexes shall be submitted to the prosecutor indicated in the warrant no later than twenty-four hours after the termination of the CI(D)A. Materials that can decrypt individuals who are sources of information on a confidential basis are not provided.

The prosecutor or investigator, at his or her instruction, investigates information received during the course of the CI(D)A. If necessary, a specialist is involved.

Persons who have or have been involved in the CI(D)A may be questioned as witnesses. The interrogation of these persons may be conducted with the secrecy of the information about these persons and with the application of the relevant security measures prescribed by law.

When used to prove the results of the CI(D)A, the persons whose actions or contacts were carried out may be questioned.

The Prosecutor shall take measures to preserve the documents and documents he / she intends to use during criminal proceedings. It is not allowed to make copies of protocols on carrying out the CI(D)A and its annexes.

The Instruction provides for the procedure for the classification and declassification of material storage media for the conduct of the CI(D)A.

Very important, both theoretically and especially, in practical terms, is the problem of realization of materials of operative development (silent investigation), since this process involves the transition from carrying out silent investigative (investigative) actions to investigative (investigative) actions of a vowel character.

The issue of the implementation of materials for operational development, as one of the central in the theory of OSA, has constantly attracted the attention of scientists. This problem was investigated by V. M. Atmazhitov, Yu. I. Veselov, G. O. Dusheiko, A. O. Mikhailichenko, M. B. Sahakyan, V. G. Samoilov and others ${ }^{2}$. The practice of operational units and the theory of OSA strongly suggests that the complexity of this stage of work on organized crime causes the need for organizational and tactical solution of the issue in the form of surgery. In their turn, A. V. Dulov, L. Ya. Drapkin, V. I. Shikanov and others ${ }^{3}$, concerning the

${ }^{2}$ Атмажитов В. М. Требования, предъявляемые к реализации оперативно-розыскной информации. Межвузовский сборник научных трудов. Омск: ВШ МВД СССР, 1985. С. 70-73; Душейко Г. О. Організаційно-тактичні основи реалізації оперативнорозшукової інформації в стадії порушення кримінальної справи : дис. ...канд. юрид. наук : 12.00.09. Харків, 2000. $271 \mathrm{c}$.

Дулов А. В. Тактические операции при расследовании преступлений. Минск: Вышейша школа, 1979. 128 с. 
problems of conducting tactical operations in the investigation of crimes in their investigations, understood under such operations the system of investigative actions, tactical techniques, OSA, organizational and other actions developed and carried out in the course of a single-plan investigation under the overall direction of the investigator in order to accomplish such a tactical task as cannot be resolved by the individual investigative action. At the same time, the investigative operation was defined by researchers as the highest organizational element of the OSA, a system of coordinated and interconnected purpose, time, location of the OSA and actions carried out on a separate plan from a single center aimed at achieving the purpose and fulfillment of the tasks of the OSA envisaged. legislation.

Thus, the implementation of operational development materials can be defined as a system of coordinated procedural actions and OSA, which allow the use in the process of investigation of data obtained in a tacit manner, with the aim of successful prevention, investigation of crimes and exposing criminals, as well as the search of persons who are hiding from an investigation, trial or serving a criminal sentence. In most cases, the implementation coincides with the start of the investigation. In this case, the investigator and the employees of the operational units solve the sole task the investigation of the identified crime (criminal activity). That is, the implementation of materials for operational development involves the implementation of a variety of OSA, CI(D)A and I(D)A, which complete the preliminary process of silent documentation of organized criminal activity, and provide the opportunity to use the materials of OSA (covert investigation) in the criminal process.

In connection with the adoption of the CCP of Ukraine in 2012.7 of the Law on OSAs "Duties of units that carry out OSAs" was supplemented by paragraphs 2-4 of the following content: " 2 . In case of detecting signs of a crime, the operational unit carrying out the OSA is obliged to immediately send the collected materials, which record the factual data about the illegal actions of individuals and groups, responsible for which are provided by the Criminal Code of Ukraine, to the appropriate body of pre-trial investigation for initiation and conduct of pre-trial investigation in the manner provided by the CPC of Ukraine. 3. If the signs of a crime are detected during a continuing ORD and termination of which may adversely affect the outcome of the criminal proceedings, the unit conducting the OSA shall notify the relevant pre-trial investigation authority and the prosecutor of the detection of the signs of the crime and finish the operational search event (allocated by us - OO), after which sends the collected materials, which record the actual data on the illegal actions of individuals and groups, the responsibility for which is provided by the Criminal Code of Ukraine, to the relevant Ghana 
preliminary investigation. "This version of Part 3 of Art. 7 of the Law "On OSA", from our point of view, needs refinement by replacing the phrase "ends the search and search event" by the same words in the plural, because within the implementation of materials for operational development ends the complex of operational search operations.

Part four of Art. 7 of the Law "On OSA" according to subparagraph 5 of paragraph 12 of the said law provides the procedure according to which the operational units spend I(D)A and CI(D)A in criminal proceedings on the instructions of the investigator, prosecutor in the manner provided by the CPC of Ukraine. Written instructions for conducting I(D)A and CI(D)A submitted to investigators, prosecutors within the competence and in due course are obligatory for execution of operational units.

Thus, these normative novelties, both legislative and departmental, that initiated the corresponding practice, allow us to raise in scientific terms the question of the theoretical concept of the unity of operative development and silent investigation of self-employed and organized crime.

\section{Operational and investigative support of criminal proceedings}

Investigation of crimes, especially those perpetrated by organized criminal groups (hereinafter referred to as OCG), is carried out through the integrated use of forces, means and methods of operative-investigative and criminalprocedural activity. Therefore, in the legal literature the issue of interaction of the investigator with the employees of the operational units has received considerable attention. From the standpoint of criminal proceedings and forensics, it was investigated by V. D. Bernaz, R. S. Belkin, G. Yu. Bondar, A. F. Volobuyev, L. Ya. Gordin, A. V. Dulov, G. G. Zuikov, V. P. Lavrov, I. V. Leshukova, I. M. Luzgin, S. V. Murashov, M. A. Pogoretsky, O. V. Starchenko and other scientists ${ }^{4}$. The issue of interaction of operational units with investigators in the fight against crime was also given considerable attention in the theory of OSA by V. M. Atmazhitov, O. M. Bandurka, M. P. Vodko, D. V. Grebelsky, V. L. Groholsky,

${ }^{4}$ Берназ П. В. Взаємодія слідчого з оперуповноваженим ДСБЕЗ при розслідуванні економічних злочинів : дис. ...кандидата юрид. наук: 12.00.09. Одеса, 2006. 200 с.; Білоус В. Т. Координація управління правоохоронними органами України по боротьбі 3 економічною злочинністю (адміністративно-правовий аспект) : дис. ...доктора юрид. наук: 12.00.07. Ірпінь, 2004. 444 с.; Бондар Г. Ю. Правове забезпечення взаємодії слідчих правоохоронних відомств у кримінальному судочинстві України : дис. ...кандидата юрид. наук: 12.00.09. Харків, 2004. 230 с.; Волобуєв А. Ф. Взаємодія слідчого з оперативними підрозділами при розслідуванні економічних злочинів. Форум права. 2006. № 1. URL: http://www.nbuv.gov.ua/e-journals/FP/2006-1/06vafrez.pdf. 
A. F. Dolzhenkov, K. K. Ermakov, I. O. Klimov, I. P. Kozachenko, M. V. Kornienko, A. G. Markushin, V. P. Khomkolov and others ${ }^{5}$.

Some scientists determine the operative-search support of the investigator's activity by a complex of legal and organizational-tactical measures that determine the interrelation and interaction of the investigative and operational units of the police department with the aim of a comprehensive, complete and objective study of the circumstances of the case, others by a complex of operational-search activities. carried out by the relevant OIA operational services to ascertain the sources and sources of information that are inherent in the methods and means of evidence to be proven in criminal proceedings for the purpose of obtaining investigative data that facilitate the establishment of truth and the taking of guilty measures provided for by law, the third - the activity of operational units to create optimal conditions for full and objective investigation, by carrying out a complex of OSA, mostly intelligence in nature, against persons who are held criminally liable, their relationships and other persons involved in the crimes being investigated, as well as neutralize their unlawful influence on procedural evidence ${ }^{6}$. Considering these definitions as a basis, we consider it necessary to clarify a number of significant points in the light of recent legislative developments.

As historically OSA was one of the means of criminal procedural cognition that enhances the latter's cognitive capabilities ${ }^{7}$, we finally witnessed this recognition when the CCP of Ukraine adopted this function in 2012 when investigative activities actually became part of criminal proceedings in criminal proceedings. the proceedings for which the pre-trial

${ }^{5}$ Гребельский Д. В. Теоретические основы и организационно-правовые проблемы оперативно-розыскной деятельности органов внутренних дел. Москва: Акад. МВД СССР, 1977. 171 с.; Грохольський В.Л. Управління діяльністю спеціальних підрозділів МВС України по боротьбі з організованою злочинністю : дис. ... доктора юрид. наук : 12.00.07. Харків, 2004. 416 с.; Водько Н. П. Организация комплексной борьбы с рецидивной преступностью. (На материалах оперативных аппаратов милиции и исправительнотрудовых учреждений). К.: РИО МВД УССР, 1981. 160 с.

${ }^{6}$ Хомколов В. П. Правовые и организационно-тактические вопросы оперативнорозыскного обеспечения деятельности следователя по установлению лица, совершившего преступление : дис. ... кандидата юрид. наук: 12.00.09. Москва, 1984. С. 13.

Бордиловский Э. П. Сущность и основные направления оперативно-розыскного обеспечения предварительного расследования групповых преступлений. Труды Академии МВД СССР. Москва: Академия МВД СССР, 1990. С. 109-115.

Рябков Е. М. Правовые, организационные и тактические вопросы оперативнорозыскного обеспечения предварительного следствия по преступлениям, совершенным группой лиц : дис. ... канд. юрид. наук. Москва, 1990. С. 20.

${ }^{7}$ Погорецький М. А. Функціональне призначення оперативно-розшукової діяльності у кримінальному процесі : монографія. Харків: Арсіс, ЛТД, 2007. С. 269-270. 
investigation was initiated. This situation, in our view, does not negate the importance of operational and investigative support of criminal justice, but on the contrary raises it to a new level, since neither the investigator nor the prosecutor, obviously, will be able to conduct any of the Criminal Code of Ukraine provided for by the Criminal Procedure Code. Without going into the discussion about the correlation between the concepts of "disclosure" and "investigation" of crimes, we emphasize that OSA and criminal procedural activity are equally in accordance with Art. 2 The CPC of Ukraine implements the requirement of legislation to ensure prompt full and impartial investigation and trial. In this connection, the Ministry of Internal Affairs of Ukraine in most of the policy documents constantly emphasizes the need to increase the role and responsibility of each National Police service in the investigation of crimes, to use all its resources and resources for this purpose ${ }^{8}$.

The term "operative-investigative support of the investigation" was first formulated in the Instruction of the Ministry of Internal Affairs of the USSR of 05.12.1984 and in subsequent normative acts of the Ministry of Internal Affairs of the USSR, which emphasized the need for operationalinvestigative support of the preliminary investigation. In the directive documents of the Ministry of Internal Affairs of Ukraine, this line of activity was named "operative-investigative support of criminal proceedings" 9 and formulated as a complex of operative-investigative measures in the interests of specific criminal proceedings in order to search and record the factual data that can be evidence in this case, to ensure complete and complete and effective investigation of the circumstances of the case, the safety of the participants in criminal proceedings, the constant informing of the bodies of pre-trial investigation and the court about the actions of the suspect $\mathrm{x}$, accused and other persons, aimed at adversely affecting the participants in criminal proceedings to counteract the establishment of truth in the case. Moreover, the term "operational support for pre-trial investigation" is also

8 Про затвердження Інструкції 3 організації взаємодії органів досудового розслідування з іншими органами та підрозділами внутрішніх справ у попередженні, виявленні та розслідуванні кримінальних правопорушень: Наказ МВС України від 14.08.2012 № 700; Про організацію реагування на повідомлення про кримінальні правопорушення, інші правопорушення, надзвичайні ситуації та інші події, та забезпечення оперативного інформування в органах і підрозділах внутрішніх справ України: Наказ МВС України від 22.10.2012 № 940.

${ }^{9}$ Про організацію діяльності Департаменту карного розшуку та підрозділів карного розшуку ГУМВС, УМВС: Наказ МВС України від 30.06.2009 № 285 [Втратив чинність]; Про затвердження Положення про Департамент карного розшуку Національної поліції України : Наказ Національної поліції України від 14.11.2015 року № 90. URL: https://www.npu.gov.ua/uk/publish/article/1813212 
used in the instructions of the Ministry of Internal Affairs of Ukraine, approved after the entry into force of the CCP $2012^{10}$.

Consistent with the substantive workload of the above definition, we cannot unequivocally accept the application of that term. Its use is not entirely justified even from the etymological point of view, since the accompaniment emphasizes only parallelism, concurrency of certain actions. Although this feature is present in the phenomenon we are investigating, its essence is mostly revealed by its active form, such as to provide or "provide material means, protect against danger, guarantee". This understanding is also borne out by the legal meaning of the term "security", in particular as regOSAs civil action or contractual obligations.

The participation of the operational units in the initiated proceedings, although carried out in accordance with Art. 41 of the CPC of Ukraine (2012), within the written mandate of the investigator, the prosecutor, however, it is not limited to the activity of procedural consolidation of factual data on the involvement of specific persons in criminal activity. Operational-search support cannot be reduced to the passive function of its support or the qualified execution of individual CI(D)A, but must be of an active security nature. According to paragraph 6 of Art. 7 of the OSA Law, operational units, in particular, are obliged to ensure, with the involvement of other units, the safety of court staff and law enforcement, assisting persons, facilitating search and search activities, are involved in criminal proceedings, their families and close relatives of these individuals. Full absorption of the operative-search function by the criminal-procedural objective cannot take place in view of its broader tasks beyond the scope of the judiciary, the presence in the structure of the OSA of other organizational-such forms: operative search (criminal intelligence) and prompt development with mandatory requirements. their offensiveness, continuity and cyclicity.

We can offer the following scientific definition of a research institute of OSA theory: operative-investigative support of criminal proceedings is a system of measures, mostly of a non-silent nature, qualified by operational units under the direction of the investigator and the prosecutor at the stages of pre-trial investigation and judicial review in order to create optimal investigations process of investigation, termination or neutralization of counteraction of participants of organized criminal group to law enforcement the equal function of the state and justice, ensuring the safety of participants in criminal proceedings.

10 Про затвердження Інструкції 3 організації взаємодії органів досудового розслідування з іншими органами та підрозділами внутрішніх справ у попередженні, виявленні та розслідуванні кримінальних правопорушень: Наказ МВС України від 14.08.2012 № 700 . 
The creation of optimal conditions for a full and objective investigation process begins at the early stages of detecting signs of crime, directly implemented within the fOCGework of the operational and investigative function of combating crime through the implementation of a complex of document the criminal activities of persons under development in the work of the established OSA. As noted earlier, documentation of its purpose and content solves problems that coincide with the institution of criminal procedural evidence, creates optimal conditions for its subsequent implementation after deciding to start a pre-trial investigation. The effectiveness and efficiency of criminal procedural evidence depends to a great extent on the completeness and reliability of the documentation. Realizing the requirements of the Law on OSAs and the CPC of Ukraine, documentation, as an organizational form of complex application of OSAs, ensures that an informed decision is made to implement the materials obtained through it through the initiation of a pre-trial investigation. It is from this moment that the stage of operative-investigative provision of procedural evidence in criminal proceedings concerning organized criminal groups (hereinafter referred to as OCG) begins.

In most cases, the moment of initiation of an investigation is related to the situation when the law enforcement authorities have established the fact of committing a specific acts of self-violence, but have not identified the person (s) who committed the crime. Prior to the adoption of the CPC of Ukraine in 2012, it was the operational units that were obliged to install such persons, working on a "crime-to-person-perpetrator" scheme. According to the current legislation, the task of identifying persons who have committed a specific organized crime is solved by conducting, on the instructions of the investigator or prosecutor, the $\mathrm{CI}(\mathrm{D}) \mathrm{A}$ by specialized operational units. Through these actions, operational units also solve the task of determining the location of the suspect, other persons involved in the crime, or who became his victim, the search for stolen objects, valuables, tools and means of committing the crime.

After establishing the event and the composition of the crime, the perpetrators of it, in order to solve the problems of timely and complete proof of the guilt of each of its participants, the degree of their organization, weapons, etc., is crucial to make such responsible procedural decisions in accordance with the rules of the CPC of Ukraine, as: notification of suspicion (Articles 276-279); identification of suspected preventive measures (Chapter 18); complex of urgent investigative (investigative) and emergency I(D)A in order to consolidate the available and to find additional evidence. The specific investigative situation at this stage requires the operational units to create optimal conditions for the execution of 
appropriate procedural decisions and actions. Therefore, there is a need for the planning and simultaneous implementation of many different abusive investigators (investigative) and $\mathrm{CI}(\mathrm{D}) \mathrm{A}$. In order to accomplish this task, investigative teams (hereinafter referred to as "IT") are set up in most cases in the course of an investigation into organized crime.

Many of the researchers who conducted investigations into the organization of crime investigations expressed the need to enshrine in the criminal procedural law the specified form of interaction of investigative and operational units under the name of the investigative-operational group. At the same time, the CPC of Ukraine, in three different articles, provides for the possibility of a group organization to investigate crimes. Particularly in Part 2 of Art. 38 states that pre-trial investigations are carried out by investigators of the pre-trial investigation body alone or by an investigative team. As well as Part 1 of Art. 37 establishes a provision according to which, if necessary, the head of the prosecutor's office may designate a group of prosecutors to exercise the powers of the prosecutor in a particular criminal proceeding, as well as a senior prosecutor of a group that will oversee the actions of other prosecutors. Article 571 "Creation and Operation of Joint Investigation Teams" sets out specific mechanisms for international cooperation.

It should be emphasized that the vast majority of criminal proceedings for organized criminal activity are carried out by the group method, that is, for the purpose of the qualified implementation of the $\mathrm{CI}(\mathrm{D}) \mathrm{A}$, the employees of the operational units are involved. This is how the operativeinvestigative support of the investigation of the criminal activity of a particular OCG happens. And, as we mentioned above, according to Part 2 of Art. 41 of the CPC of Ukraine, employees of operational units in the performance of investigator's orders, including in the work of the work of the IT, use the powers of the investigator.

Studying the practice of investigating organized crime has made it possible to formulate a number of proposals for its structural and functional improvement. Based on the specifics of working in criminal investigations on crimes of the investigated category, which is to ensure strict observance of the principles of confidentiality, prevention of information leakage, an important aspect of organizing the work of the group we see the issue of dividing the members of the IT into three levels of awareness of the circumstances of the investigated organized activities investigations (levels of access to information). These levels of access are also created to counteract intelligence activities as a means of counteracting the pre-trial investigation being undertaken by OCG members and their connections at large. 
The highest level of access to information, that is, the entire range of IT activities, should be enjoyed by those involved in the work of the Group Headquarters. The headquarters of the IT must include: Senior Investigative Team in accordance with paragraph 1 of Part 2 of Art. 39 of the CPC of Ukraine; the leader of the operational wing of the group (usually at the level of the leader or deputy leader of the relevant operational unit); the most experienced employees of the operational units. In accordance with the requirements of Part 1 of Art. 37 of the CPC of Ukraine is objective that the IT staff should include a prosecutor or a group of prosecutors with a senior prosecutor of such a group. According to the provisions of the CPC of Ukraine, a prosecutor or a group of prosecutors within the IT staff, in the function of supervising the observance of laws during the pre-trial investigation, exercise procedural guidance over them. They undoubtedly have greater powers than the formal SG supervisor - investigator (see Part 2 of Article 36 of the CCP). This is a significant problem, the solution of which remains the task of science, law enforcement and the legislature. At the same time, it is undesirable to exceed the total number of persons involved in the work of the staff, 6-7 employees, but, nevertheless, in each case the composition of the HQ staff is determined by its head, based on the specific circumstances of criminal proceedings, the degree of its complexity and the number of episodes under investigation.

The next level of awareness of the circumstances of the crime and the measures taken to disclose it, should be owned by persons involved in working in a subgroup to work out specific case information or individual versions. The IT leader should dispense information provided to employees involved in the work of this subgroup, to the extent necessary for the qualitative completion of specific tasks and completion of individual versions provided for in the work plan. This subgroup includes investigators who are recruited by the SG supervisor through the adoption of a relevant resolution, as well as members of operational units. As a rule, the total membership of this group should not exceed 10 people. In the event that there is a need to expand the group of members during the development of additional versions or after the perpetrators have been established, the composition of this group may be expanded by issuing an additional resolution of the investigator to change the composition of the IT.

Specialized Rapid Response Officers of the KORD, the patrol police involved in the work of the IT, form a group of assigned forces. This group has the least awareness of the circumstances of the crime and the measures being taken in its investigations. These employees are directly involved in conducting tactical operations according to the plans developed, assist in the conduct of individual investigative (search) 
actions, exercise physical protection of the participants of criminal proceedings and act on the basis of information provided to them by the IT management during careful briefing.

As a separate direction of creating optimal conditions for a complete and objective investigation process in the work of the operative and investigative support of organized criminal proceedings, it is necessary to recognize the provision of practical implementation of the use of confidential cooperation as the CI(D)A, provided for in Art. $275 \mathrm{CPC}$ of Ukraine. Pursuant to Part 1 of the said Article, the investigator has the right to use the information obtained as a result of confidential cooperation with other persons, or to involve them in the conduct of the CI(D)A. At the same time, the answer but up to item 13 of Art. 8 of the Law on OSA, which provides for the right of operational units, in particular, to have non-public staff and freelance employees, the subject of establishing and direct implementation of such confidential cooperation is an employee of the operational unit.

The use of confidential cooperation is most effective at the initial stage of the investigation in the form of prompt detention of detainees. The psychological situation of their isolation from the accomplices and habitual social environment, which causes the natural necessity of communication, allows to obtain, by means of expedited working out, the actual factual data. The advantages of this form of operational investigative support for the investigation of OSA are that the information obtained in compliance with the rules of conspiracy can be immediately involved in the process of proving by conducting investigative (investigative) and $\mathrm{CI}(\mathrm{D}) \mathrm{A}$. This ensures that the principles of completeness and objectivity are proven. Unfortunately, the aforementioned possibilities are not used to full capacity, as at the stage of judicial review the operational work is mostly unreasonably terminated, and the prospecting work at the stage of court proceedings is generally used in exceptional cases by court decision. This issue remains unregulated.

The cessation or neutralization of the opposition of the members of the OSA to the enforcement of the law-enforcement function of the state and justice is one of the important areas of operational and search support, which has received much more attention ${ }^{11}$.

11 Александренко О. В. Криміналістичні проблеми подолання протидії розслідуванню: дис. ...канд. юрид. наук : 12.00.09. Київ, 2003. 183 с.; Карагодин В. Н. Преодоление противодействия предварительному расследованию. Свердловск: Изд-во Уральского ун-та, 1992. 247 с. 
The analysis of these publications and the materials of our own research showed that the means of counteraction to the criminal environment are many, and their tactics are quite diverse. Therefore, it is impossible to limit yourself to one, though very effective, method of overcoming such opposition. It is established that OCG, taking countermeasures, mainly operates in two directions: blocking agent penetration into their environment (13\%), as well as finding sources of leakage of information on operational development, plans of investigation and planned operative-search (tactical) operations (12\%). In the hierarchy of specific criminal acts, the following measures are identified: detection, bribery, intimidation and other influence on the victims and witnesses in order to persuade them to give "necessary" grouping of testimonies $(10 \%)$; making maximum use of the imperfections of the current system of detention in penitentiary institutions for the purpose of establishing illegal channels of communication with arrested participants of the OCG and coordinating counter-measures $(9 \%)$; hiring high-quality attorneys for the means of "obshak", creating advocacy groups for the investigators $(9 \%)$ concealing suspects outside Ukraine and providing them with false documents $(10 \%)$; destruction of traces of weapons and means of criminal activity (10\%); simulation of diseases (1\%); pressure through the media (5\%); deliberate discrediting of operatives, investigators, prosecutors, investigating judges and judges, including through defamation contained in complaints and statements (2\%); the use of corrupt communications, as well as bribery of investigators, prosecutors, officers of the operative units, investigative judges, judges (10\%); Attempt to recruit the said parties to the prosecution on the side of the prosecution on material (9\%) and so on.

At the same time, the researchers discuss the tactics of counteraction of the OCG to law enforcement agencies by grouping specific actions, which are divided into the following blocks of measures: 1) a block of measures that organize criminal activity; 2) a block of measures aimed at ensuring the technical superiority of OCG over law enforcement agencies; 3) a block of measures to ensure the concealment of criminal activity; 4) actions aimed at creating an effective system of contacts in the structures of the authorities to ensure the guaranteed protection of their interests and the safety of the members of the group; 5) actions aimed at protecting economic and political power in the regions; 6) forceful pressure on the part of the society in which respect for law and order was formed, on the authorities, whose functions include the protection of the rights and freedoms of citizens ${ }^{12}$.

12 Теория оперативно-розыскной деятельности : учебник / [ под ред. К. К. Горяинова, В. С. Овчинского, Г. К. Синилова ]. Москва: ИНФРА-М, 2008. С. 497-500. 


\section{CONCLUSIONS}

From the mentioned measures of counteraction of the OCG to the accomplishment of the tasks of criminal justice, it can be concluded that the operative-search support of the latter requires the qualified application of the system of the CI(D)A.

In order to stop or neutralize the counteraction of the criminal environment at the stages of pre-trial investigation or trial, it is advisable to use: 1) the performance of a special task for the disclosure of criminal activities of $\mathrm{CO}$ or the $\mathrm{CC}$ (Article $272 \mathrm{CCP}$ ); 2) the use of confidential cooperation (Article 275 of the CCP); 3) conducting surveillance of a person, thing or place (Article 269 of the CCP) in the environment of participants in criminal proceedings, their official or domestic environment, as well as active visitors to court hearings; 4 ) in the presence of appropriate grounds, the use of operational and technical means of control of the actions developed and documentation of their illegal activities. Aggregate The findings of factual findings and methods of counteracting the investigation or trial so identified may, at the discretion of the investigator, prosecutor or judge, be directly annexed to the criminal proceedings concerning organized crime. Evidence obtained, depending on the nature and form of the counteraction, may be the basis for deciding whether to bring the perpetrators to administrative or criminal liability. The timeliness of the implementation of the $\mathrm{CI}(\mathrm{D}) \mathrm{A}$ to identify, document the facts of counteraction to the criminal environment creates favorable conditions for an objective and complete pre-trial investigation and trial of organized criminal activity.

\section{SUMMARY}

In the article it is proved that the following basic tasks are solved during the operative development and silent investigation: prevention or cessation of serious or especially serious crimes, which are being prepared; establishment of all members of the group, functions of each; documentation of specific facts (episodes) of criminal acts; preventing the possibility of those who are being developed to evade the investigation and the court, to counteract the establishment of the truth, to ensure the safety of the participants of the operative-investigative activity, the criminal proceedings, the employees of the court and the law-enforcement bodies, their relatives. Other tasks include: identifying ways to engage new members, corrupt relationships, creating your own security system and organizing counteraction to the law enforcement system; establishment of the fact of existence of general funds of the group, system of distribution of criminal incomes, their legalization; 
ensuring compensation for material losses caused by the actions of the developed and their accomplices; detention of wanted criminals; identifying and eliminating conditions conducive to crime.

It is determined that the ways of achieving the outlined tasks in the new procedural conditions are: introduction at the departmental level of the possibility of gradual implementation of special units of operational developments of criminal organizations by bringing to responsibility both individual developed and organized groups, which are structural parts of such groups; use of tools of silent investigation with simultaneous or parallel conducting of operational development of other structural units of the detected criminal group.

It is proposed to determine the operative-search support of criminal proceedings as a system of measures, mostly of a vague nature, carried out by operational units under the direction of the investigator and the prosecutor at the stages of pre-trial investigation and trial in order to create optimal conditions for a full and objective process of investigation, termination or neutralization of participants criminal group for the performance of the law enforcement function of the state and justice, ensuring the safety of Crimean participants legal proceedings.

\section{REFERENCES}

1. Александренко О. В. Криміналістичні проблеми подолання протидії розслідуванню: дис. ...канд. юрид. наук : 12.00.09. Київ, 2003. $183 \mathrm{c}$.

2. Бордиловский Э. П. Сущность и основные направления оперативно-розыскного обеспечения предварительного расследования групповых преступлений. Труды Академии МВД СССР. Москва: Академия МВД СССР, 1990. С. 109-115.

3. Карагодин В.Н. Преодоление противодействия предварительному расследованию. Свердловск: Изд-во Уральского ун-та, 1992. $247 \mathrm{c}$.

4. Погорецький М. А. Функціональне призначення оперативнорозшукової діяльності у кримінальному процесі : монографія. Харків: Арсіс, ЛТД, 2007. 576 с.

5. Рябков Е. М. Правовые, организационные и тактические вопросы оперативно-розыскного обеспечения предварительного следствия по преступлениям, совершенным группой лиц : дис. ... канд. юрид. наук. Москва, 1990. 200 с.

6. Теория оперативно-розыскной деятельности : учебник / [под ред. К. К. Горяинова, В. С. Овчинского, Г. К. Синилова]. Москва: ИНФРА-М, 2008. 832 с. 
7. Хомколов В.П. Правовые и организационно-тактические вопросы оперативно-розыскного обеспечения деятельности следователя по установлению лица, совершившего преступление : дис. ... кандидата юрид. наук: 12.00.09. Москва, 1984. 200 с.

Information about the author: Podobnyi O. O., Doctor of Laws, Professor, Head of the Department of Criminal Law, Process and Criminalistics, International Humanities University 33, Fontanska Road str., Odessa, 65009, Ukraine 